Bull. Chem. Soc. Sthiop. 2000, 14(1), 1-8.

Printed in Ethiopia

\title{
A STUDY OF THE WATER QUALITY OF THE OSUN RIVER: METAL MONITORING AND GEOCHEMISTRY
}

\author{
A.A." Olajire and F.E. Imeokparia \\ Department of Pure and Applied Chemistry, Ladoke Akintola University of Technology,
Ogbomoso, Nigeria
}

(Received October 27. 1999; revised March 24, 2000)

\begin{abstract}
The concentrations and distributions of $\mathrm{Cd}, \mathrm{Cu}, \mathrm{Ni}, \mathrm{Pb}, \mathrm{Cr}$ and $\mathrm{Zn}$ in Osun river selected rivers in the region and groundwaters have been studied, in order to establish the current levels of pollution. The metal concentration (mean $\pm R S D$ in $\mu \mathrm{g} \mathrm{dm}^{3}$ ) in the Osun river for the sampling $21.8 \pm 6.22,10.6 \pm 3.68,15.3 \pm$ August, respectively, were: Cd, $1.45 \pm 0.65,1.40 \pm 0.37,1.25 \pm 0.52$; Ni, $8.27 \pm 3.80 ; \mathrm{Cr}, 250 \pm 118,400 \pm 160,150 \pm 72.9 ; 8.45 \pm 3.24,4.86 \pm 1.98 ; \mathrm{Cu}, 16.7 \pm 9.32,11.9 \pm 4.81$, coefficient between metal pairs of rive $150 \pm 72.9 ; \mathrm{Zn}, 398 \pm 109,289 \pm 113,259 \pm 94.4$. The correlation sources of the polluting substances are discussed.
\end{abstract}

\section{INTRODUCTION}

The supply of fresh water is the most important economic role of rivers, and for this reason, the quality of river waters must be constantly monitored. Most developing countries face the enomous challenge of improving living standards against a backdrop of serious environmental problems. For instance, because rivers and streams have been considered a convenient means of cleaning and carrying wastes away from the discharge points, most rivers in urban areas are highly loaded with urban and industrial wastes [1,2].

Heavy metals gain access into the river system from both natural and anthropogenic sources, and get distributed in water body. suspended sediments and bed sediments during the course of their transport. The natural weathering of rocks on land and volcanic activity introduce these heavy metals into the river and seas, but in many instances, they occur at unnaturally high concentrations because of mining activities and other industrial processes [3]. The trace metal content of river waters is normally controlled by the abundance of metals in the rocks of the river's catchment area, and by their geochemical mobility. Thus, a catchment area containing mineralized rocks will usually have elevated metal levels in the waters and sediments of the river draining it $[4,5]$. However. very high levels of metal ions in rivers are normally associated with polluting discharges and/or metalliferous mining and smelting activities [6-10]. Since geologica] and anthropogenic inputs dominate the carrier compartment of the water body of a river system. hence the river waters of the World are bound to vary in their heavy metal concentrations and
distributions.

In large enough doses, these metals can prove lethal to organisms, including humans. Heavy metals, therefore constitute another major category of pollutants in rivers, coastal waters and seas
[3].

The present study is significant in that water, and land, the vital resources of life are increasingly being polluted in the wake of popular growth, poor land use system, agricultural activities, industrialization and anthropogene impact on the study area.

In this paper, the results of a chemical monitoring study of metals in the Osun river are 
reported. The data from this investigation will provide information regarding the quality of river water and groundwater source types.

Historical perspective. The geology of the river Osun's catchment area comprises predominantly Pre-Cambrian rocks. the so-called basement complex from which the fairly clayey loam of the surrounding district is derived [11,12]. River Osun bears its origin from Igede Ekiti, flows through Ilesha forest and enters Osogbo at the West. Osun river has a number of tributaries that join it at Osogbo, these include Ajibu river, Okoko river, Ogbaagba river, Asaba river and Elekunkun river. Apart from the use of the Osun river for miraculous deeds as believed by the Osun worshippers, it also constitutes a water source for the people residing downstream.

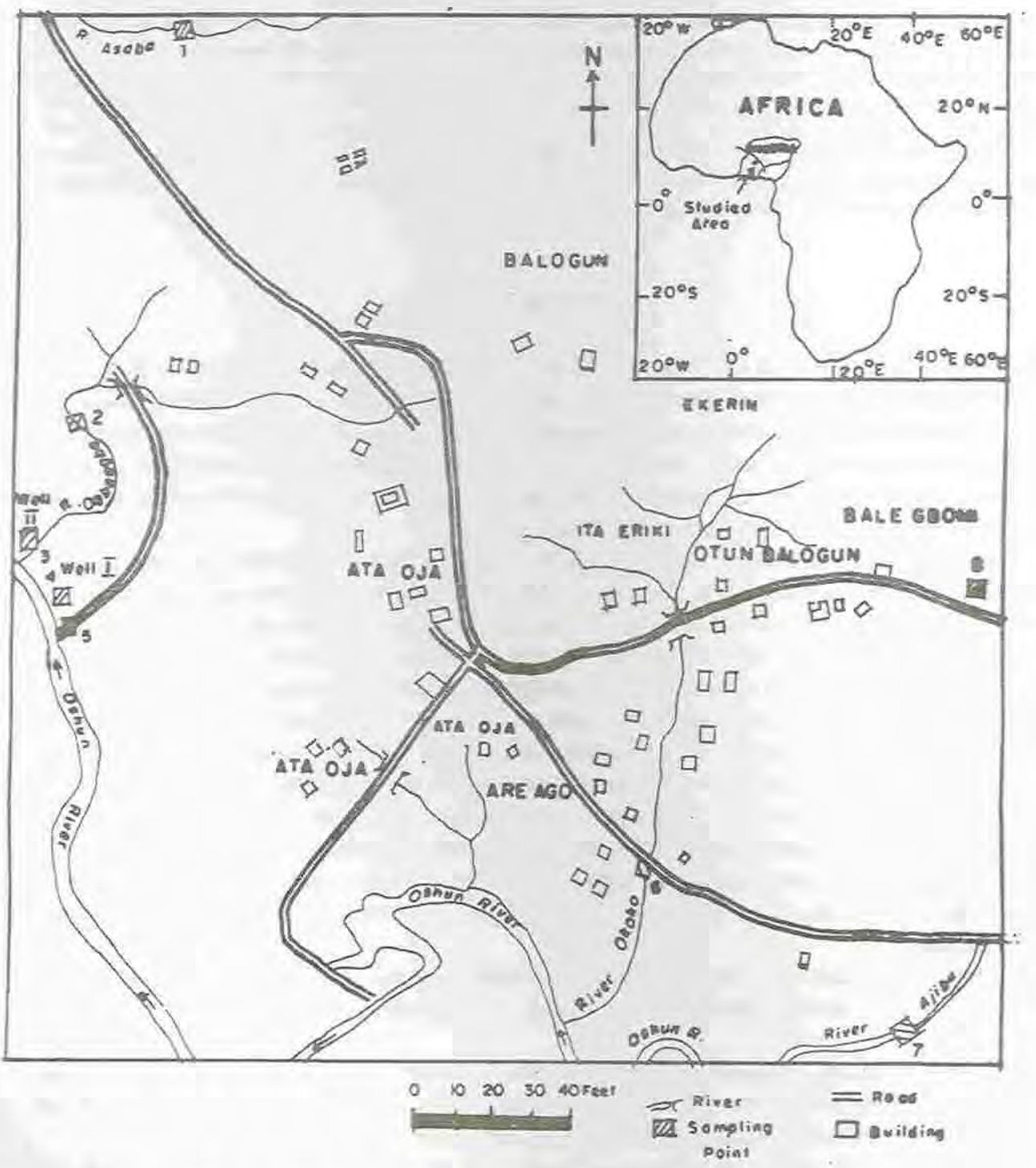

Figure 1. Map of Osogbo showing sampling locations. 
There are quite a number of industries located in Osogbo, the state capital of the Osun State, Nigeria, and therefore the major cause of pollution is the high load of urban and industrial wastes poured into the river. Moreso, the river receives a wide variety of substances along with garbage from anthropogenic sources as well as its tributaries, causing a subject of immediate attention.

\section{MATERIALS AND METHODS}

Sampling. A short term field survey of Osun river was carried out in order to locate the important sources of pollution. Stations for the collection of river water samples include locations along all the tributaries that enter the river as well as the main stem of the river (Figure 1). The river was sampled on three occasions: May 28, 1998; June 30, 1998 and August 26, 1998.

Station 1, which is river Asaba (RA1) is located on the north branch of the river, just upstream of river Osun. Station 2 is river Ogbaagba (RO2), located on the north-west side of the river while stations 3 and 4 (i.e. WE3 and WE4, respectively) are groundwater stations, located near river Osun; these wells serve as the current water supply for residents and businesses of people in the area. Station 5 is the river Osun (RS5), located on the western part of Osogbo town, the capital of Osun State, Nigeria. Stations 6 and 7 are rivers Okoko and Ajibu (i.e. RK6 and RB7, respectively), also tributaries to river Osun, and are located on the south-east branch of the river. These stations serve as the main source of water for people residing downstream. Station 8 is river Elekunkun (RE8), located on east branch of the river.

River water samples were taken from the surface of the river (upper $50 \mathrm{~cm}$ ) and groundwater samples at two well locations near the river Osun using a $2 \mathrm{dm}^{3}$ capacity teflon container that had been pre-rinsed with organic solvents and acid leached. Samples were taken at each station (Figure 1) nine times over the course of a 24 -hour period; that is about three hours apart. All sampling stations were located between 150 and 200 meters away from industrial or municipal discharge points. Storage and treatment of water samples were done according to Fresenius et al., [13] and APHA [14].

Atomic absorption analysis. The water samples $\left(500 \mathrm{~cm}^{3}\right)$ were acidified with $10 \mathrm{~cm}^{3}$ of concentrated nitric acid and concentrated up to $25 \mathrm{~cm}^{3}$ using evaporation method [15]. After chelation, extraction and subsequent mineralization, $\mathrm{Cd}, \mathrm{Cr}, \mathrm{Cu}, \mathrm{Zn}, \mathrm{Ni}$ and $\mathrm{Pb}$ concentrations were measured with a Pye Unicam 919 atomic absorption spectrophotometer. An air-acetylene flame was used for all elements. The instrument was operated as per the instrument's manual. The blanks were used for zeroing the instrument before each analysis to avoid matrix interference.

Analytical precision. The reproducibility of the analytical procedures were checked by carrying out a duplicate analysis. Duplicate results did not differ by more than $5 \%$ of the mean.

Replicability of sampling was determined by collection of multiple samples at station 5 . Briefly, 9 samples were collected over a two-hour period and were combined to give three samples that were time averaged over the collection interval. These samples were analysed in duplicate for trace metals. The overall variability ranged from $5.7 \%$ r.s.d. for zinc to $24.8 \%$ r.s.d. for $\mathrm{Cu}$ with the average sampling variability of $14.6 \%$

\section{RESULTS AND DISCUSSION}

The sampling locations including two groundwater samples are shown in Figure 1. The objectives 
of the present investigation were to find out the status of the trace elements in river Osun. selected rivers in the region and groundwaters. The analytical results given in Tables $1-3$ are the means (and standard deviations) and the ranges of data for 9 samples taken from each location for the three sampling dates. Generally, cadmium, lead, chromium, zinc and nickel are classified as highly toxic and considered responsible for health hazards. whereas copper is less toxic in nature [16-18]. There was no regular pattern in the riverain metal distributions but the levels of cadmium, nickel and zinc in river Osun were higher than the contributions of the various point sources (Tables 1.2), indicating that some other sources, may be contributing these metals to the river system. The concentrations of lead, copper and chromium were also higher than other sources except for August survey, where the lead, chromium and copper contents of point sources were higher than the river Osun. On an overall basis, the metal concentrations varied substantially over the sampling periods (Table 1). Generally, the May sampling exhibited the highest metal concentrations: nickel. copper and zinc were significantly higher than the other surveys while lead was only somewhat elevated. The cadmium concentration was approximately equal for both May and June surveys and slightly higher than August survey, although in terms of environmental, analytical and instrumental variables, the concentrations are essentially the same. Chromium showed highest concentration in June than the other surveys.

Table I. Total metal concentrations $\left(\mu \mathrm{gg} \mathrm{dm}{ }^{-3}\right)$ in Osun river water samples for the three sampling dates.

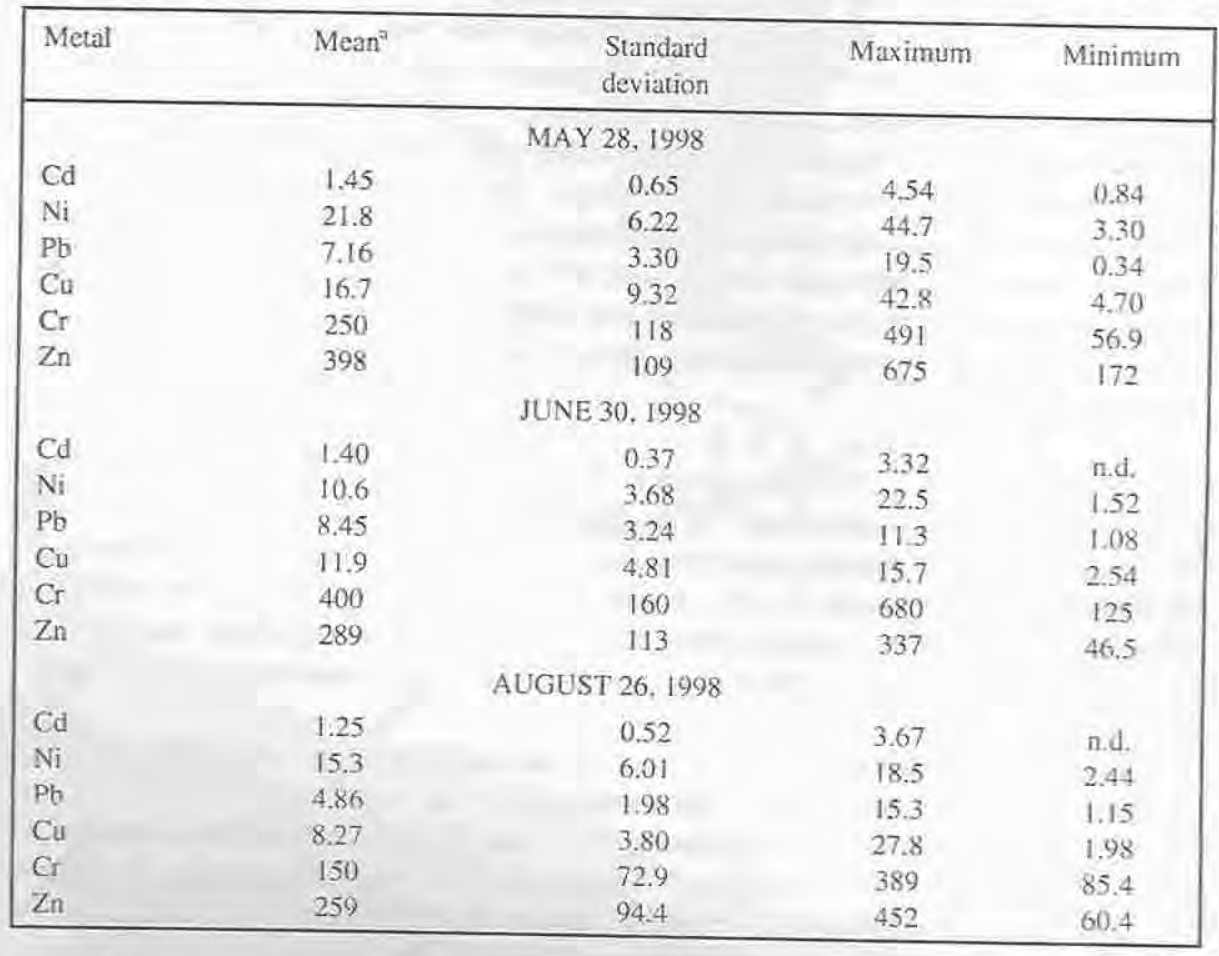

"Means of duplicate analysis and 9 sampling; n.d. $=$ not detected.

Water samples from other rivers in the region were also analyzed (Table 2) and most were found to have lower metal concentrations than those found in the Osun river, indicating the low 
level of mineralization and industrial activity in their catchment area. The high lead and copper concentrations in Ajibu and Elekunkun rivers (i.e. RB7 and RE8. respectively) during August survey were probably caused by industrial pollution and/or intentional dumping of wastes and wastewaters that are rich in leaded and cuprous materials into these rivers.

Table 2. Total metal concentrations ( $\alpha \mathrm{g} \mathrm{dm}$ ) in other rivers of Osoghe region for the three sampling dates.

\begin{tabular}{|c|c|c|c|c|c|c|c|}
\hline $\begin{array}{l}\text { Sampling } \\
\text { date }\end{array}$ & $\begin{array}{c}\text { Sample } \\
\text { code }\end{array}$ & Cil & $\mathrm{Ni}$ & $\mathrm{Ph}$ & $\mathrm{Cu}$ & $\mathrm{Cr}$ & $\mathrm{Zn}$ \\
\hline \multirow{5}{*}{$\begin{array}{c}\text { MAY } 28 . \\
1998\end{array}$} & RAI & $\begin{array}{l}0.74^{\prime \prime}(0.19) \\
\text { n.d. }{ }^{\mathrm{h}}-2.05^{c} \\
\end{array}$ & $\begin{array}{r}6.48(1.66) \\
1.04-9.72 \\
\end{array}$ & $\begin{array}{l}2.15(0.94) \\
\text { n.d. }-3.61\end{array}$ & $\begin{array}{l}3.50(1.65) \\
1.04-7.33 \\
\end{array}$ & $\begin{array}{l}200(74.5) \\
49.6-398 \\
\end{array}$ & $\begin{array}{l}198(69.4) \\
77.2-275 \\
\end{array}$ \\
\hline & $\mathrm{RO}_{2}$ & $\begin{array}{l}0.35(0.10) \\
\text { a.d. }-1.65\end{array}$ & \begin{tabular}{|l|}
$8.10(2.95)$ \\
$2.17-12.4$ \\
\end{tabular} & $\begin{array}{l}1.89(0.52) \\
0.24-3.66 \\
\end{array}$ & $\begin{array}{l}4.14(1.79) \\
1.56-8.02 \\
\end{array}$ & $\begin{array}{l}155(59.2) \\
50.1-297 \\
\end{array}$ & $\begin{array}{l}157(46.1) \\
43.5-216 \\
\end{array}$ \\
\hline & RK6 & $\begin{array}{l}0.82(0.21) \\
0.14-1.92 \\
\end{array}$ & $\begin{array}{l}5.64(1.76) \\
1.28-7.49 \\
\end{array}$ & $\begin{array}{l}3.45(1.02) \\
0.78-8.22 \\
\end{array}$ & $\begin{array}{l}6.99(2.56) \\
2.57-14.3 \\
\end{array}$ & $\begin{array}{c}201(74,3) \\
57.4-387 \\
\end{array}$ & $\begin{array}{l}173(55.4) \\
42.1-237 \\
\end{array}$ \\
\hline & RB7 & $\begin{array}{l}0.64(0.18) \\
0.21-1.08 \\
\end{array}$ & $\begin{array}{l}10.4(3.82) \\
2.91-15.2 \\
\end{array}$ & $\begin{array}{l}5.32(1.84) \\
1.66-9.72 \\
\end{array}$ & $\begin{array}{l}11.3(4.72) \\
3.44-25.8 \\
\end{array}$ & $\begin{array}{l}174(63,4) \\
44,8-298 \\
\end{array}$ & $\begin{array}{l}194(57.0) \\
64.7-284 \\
\end{array}$ \\
\hline & RE8 & $\begin{array}{l}0.46(0.10) \\
\text { n.d. }-1.32\end{array}$ & $\begin{array}{l}7.65(1.99) \\
\text { n.d. }-16.8 \\
\end{array}$ & $\begin{array}{l}6.04(2.11) \\
0.45-15.9 \\
\end{array}$ & $\begin{array}{l}8.64(3.46) \\
2.14-19.7 \\
\end{array}$ & $\begin{array}{c}181(60.5) \\
51.6-305 \\
\end{array}$ & $\begin{array}{l}142(39.8) \\
20.6-194 \\
\end{array}$ \\
\hline \multirow{5}{*}{$\begin{array}{c}\text { JUNE } 30 . \\
1998\end{array}$} & RAI & $\begin{array}{l}0.52(0.12) \\
\text { n.d. }-1.34\end{array}$ & $\begin{array}{l}4.71(1.80) \\
1.06-8.92 \\
\end{array}$ & $\begin{array}{l}3.22(1.04) \\
0.91-8.10 \\
\end{array}$ & $\begin{array}{l}5.54(2.72) \\
1.11-9.72 \\
\end{array}$ & $\begin{array}{l}167(66.8) \\
46.7-271\end{array}$ & $\begin{array}{l}108(36.5) \\
36.4-261 \\
\end{array}$ \\
\hline & $\mathrm{RO} 2$ & $\begin{array}{l}0.37(0.11) \\
\text { n.d, }-1.08\end{array}$ & $\begin{array}{l}7.23(2.62) \\
2.15-14.8 \\
\end{array}$ & $\begin{array}{l}1.98(0.46) \\
\text { n.d. }-3.02 \\
\end{array}$ & $\begin{array}{l}6.18(3.16) \\
1.50-10.2 \\
\end{array}$ & $\begin{array}{l}221(69.4) \\
68.7-417 \\
\end{array}$ & $\begin{array}{l}136(42.1) \\
21.0-297 \\
\end{array}$ \\
\hline & RK6 & $\begin{array}{c}0.56(0.22) \\
0.11-2.09 \\
\end{array}$ & \begin{tabular}{|c|}
$3.42(0.91)$ \\
$0.66-7.98$ \\
\end{tabular} & $\begin{array}{l}5.22(2.05) \\
\text { n.d. }-11.8 \\
\end{array}$ & $\begin{array}{l}8.49(4.06) \\
1.07-13.6 \\
\end{array}$ & $\begin{array}{l}246(90.4) \\
74.6-418 \\
\end{array}$ & $\begin{array}{l}141(40.5) \\
37.4-226 \\
\end{array}$ \\
\hline & RB7 & $\begin{array}{c}0.88(0.27) \\
0.24-2.76\end{array}$ & \begin{tabular}{|l|}
$6.14(1.78)$ \\
$1.28-12.9$ \\
\end{tabular} & $\begin{array}{l}7.19(2.47) \\
2.16-15.2 \\
\end{array}$ & $\begin{array}{c}9.65(4.32) \\
1.64-18.8 \\
\end{array}$ & $\begin{array}{l}198(75.3) \\
49.6-307 \\
\end{array}$ & $\begin{array}{l}162(51,0) \\
28.1-270 \\
\end{array}$ \\
\hline & RE8 & $\begin{array}{l}0.66(0.16) \\
\text { n.d. }-1.82\end{array}$ & \begin{tabular}{|l|}
$9.83(2.57)$ \\
$2.71-18.4$ \\
\end{tabular} & $\begin{array}{l}4.06(1.63) \\
\text { n,d. }-11.4 \\
\end{array}$ & $\begin{array}{l}10.2(4.50) \\
2.32-16.9 \\
\end{array}$ & $\begin{array}{l}239(112) \\
52.9-364 \\
\end{array}$ & $\begin{array}{l}159(49.7) \\
39.6-217 \\
\end{array}$ \\
\hline \multirow{5}{*}{$\begin{array}{l}\text { AUGUST } \\
26,1998\end{array}$} & RAI & $\begin{array}{l}0.69(0.24) \\
\text { n.d. }-1.34 \\
\end{array}$ & $\begin{array}{l}3.33(0.66) \\
0.21-7.92 \\
\end{array}$ & $\begin{array}{l}3.75(1.35) \\
1.04-6.77 \\
\end{array}$ & $\begin{array}{l}5.98(2.08) \\
1.07-8.77 \\
\end{array}$ & $\begin{array}{l}161(65.2) \\
73.4-245 \\
\end{array}$ & $\begin{array}{l}201(78.4) \\
48.1-392 \\
\end{array}$ \\
\hline & $\mathrm{RO} 2$ & $\begin{array}{l}0.5 \mathrm{I}(0.18) \\
\text { n.d. }-1.42 \\
\end{array}$ & $\begin{array}{l}9.18(3.42) \\
2.42-17.3 \\
\end{array}$ & $\begin{array}{l}3.99(1.27) \\
1.37-7.48 \\
\end{array}$ & $\begin{array}{l}6.72(2.30) \\
1.21-11.8 \\
\end{array}$ & $\begin{array}{r}229(109) \\
81.9-409 \\
\end{array}$ & $\begin{array}{l}187(49.8) \\
29.4-305 \\
\end{array}$ \\
\hline & RK6 & $\begin{array}{r}1.01(0.46) \\
0.21-2.88 \\
\end{array}$ & $\begin{array}{l}4.96(1.83) \\
1.78-10.6 \\
\end{array}$ & $\begin{array}{l}4.50(1.80) \\
1.29-13.2 \\
\end{array}$ & $\begin{array}{r}9.01(1.97) \\
1.30-15.3 \\
\end{array}$ & $\begin{array}{c}214(85.3) \\
60.4-390 \\
\end{array}$ & $\begin{array}{c}195(60.4) \\
31.7-279 \\
\end{array}$ \\
\hline & RB7 & $\begin{array}{l}0.28(0.05) \\
\text { n.d. }-0.94\end{array}$ & $\begin{array}{l}9.42(4.03) \\
2.32-14.8 \\
\end{array}$ & $\begin{array}{l}8.09(2.75) \\
2.40-17.2 \\
\end{array}$ & $\begin{array}{l}10.4(3.42) \\
1.80-16.9 \\
\end{array}$ & $\begin{array}{l}207(82.7) \\
58.1-367 \\
\end{array}$ & $\begin{array}{l}144(54.2) \\
28.2-246\end{array}$ \\
\hline & RE8 & $\begin{array}{l}0.78(0.29) \\
\text { n.d. }-1.89 \\
\end{array}$ & $\begin{array}{c}6.05(2.33) \\
1.43-11.5 \\
\end{array}$ & $\begin{array}{l}7.92(3.04) \\
2.15-18.5 \\
\end{array}$ & $\begin{array}{l}12.6(4.69) \\
2.98-24.9 \\
\end{array}$ & $\begin{array}{l}224(70.5) \\
51.6-348 \\
\end{array}$ & $\begin{array}{l}102(43.3) \\
21.8-165\end{array}$ \\
\hline
\end{tabular}

Values in parenthesis are the standard deviation, $\sigma_{\mathrm{n}: \mathrm{i}} ;$ means of duplicate analysis and 9 sampling; ${ }^{\mathrm{b}}$ minimum value; 'maximum value; n.d. $=$ not detected.

Metal concentrations in groundwater samples near the Osun river were determined in order to evaluate their significance with respect to other metal sources. The data showed that of the metals evaluated, WE4 samples had, generally, higher concentrations than WE3 samples (Table 3). This was particularly obvious for copper during June survey and lead and zinc during May Survey. 
The concentrations of all the metals in groundwater samples were substantially lower than those found in river Osun water samples, negating groundwater as a possible source of the metals in the river system.

Table 3. Total metal concentrations $\left(\mu \mathrm{g} \mathrm{dm}{ }^{-3}\right)$ in groundwater samples for the three sampling dates.

\begin{tabular}{|c|c|c|c|c|c|c|c|}
\hline $\begin{array}{c}\text { Sampling } \\
\text { Date }\end{array}$ & $\begin{array}{c}\text { Sample } \\
\text { Code }\end{array}$ & $\mathrm{Cd}$ & $\mathrm{Ni}$ & $\mathrm{Pb}$ & $\mathrm{Cu}$ & $\mathrm{Cr}$ & $\mathrm{Zn}$ \\
\hline \multirow[b]{2}{*}{$\begin{array}{c}\text { MAY 28, } \\
1998\end{array}$} & WE3 & $\begin{array}{l}0.43^{\mathrm{a}}(0.12) \\
0.02^{\mathrm{b}}-0.92^{\mathrm{c}}\end{array}$ & $\begin{array}{l}5.17(2.46) \\
1.10-9.46\end{array}$ & $\begin{array}{c}1.26(0.48) \\
\text { n.d. }-2.07\end{array}$ & $\begin{array}{c}6.04(2.30) \\
1.18-10.9\end{array}$ & $\begin{array}{c}60.1(20.4) \\
15.6-108\end{array}$ & $\begin{array}{l}103(21.9) \\
26.9-194\end{array}$ \\
\hline & WEA & $\begin{array}{l}0.28(0.10) \\
\text { n.d. }-0.67\end{array}$ & $\begin{array}{r}8.19(3.42) \\
1.46-12.3\end{array}$ & $\begin{array}{c}2.91(1.28) \\
0.08-4.63\end{array}$ & $\begin{array}{l}4.69(1.98) \\
\text { n.d. }-10.1\end{array}$ & $\begin{array}{r}48.6(18.5) \\
11.9-97.3\end{array}$ & $\begin{array}{l}185(36.2) \\
34.6-257\end{array}$ \\
\hline \multirow[b]{2}{*}{$\begin{array}{c}\text { JUNE } 30 . \\
1998\end{array}$} & WE3 & $\begin{array}{l}0.59(0.20) \\
\text { n.d. }-0.96\end{array}$ & $\begin{array}{l}6.32(2.71) \\
0.98-9.04\end{array}$ & $\begin{array}{l}0.87(0.30) \\
\text { n.d. }-1.75\end{array}$ & $\begin{array}{l}2.60(0.96) \\
\text { nd. }-5.55\end{array}$ & $\begin{array}{l}74.2(25.2) \\
\text { n.d. }-116\end{array}$ & $\begin{array}{l}161(29.3) \\
33.5-219\end{array}$ \\
\hline & WEA & $\begin{array}{l}0.36(0.16) \\
0.04-0.82\end{array}$ & $\begin{array}{c}6.60(2.50) \\
1.06-12.4\end{array}$ & $\begin{array}{l}1.04(0.36) \\
\text { n.d. }-1.68\end{array}$ & $\begin{array}{c}8.39(3.57) \\
1.42-14.9\end{array}$ & $\begin{array}{c}82.9(28.4) \\
21.6-139\end{array}$ & $\begin{array}{l}142(48.3) \\
46.8-197\end{array}$ \\
\hline \multirow[b]{2}{*}{$\begin{array}{l}\text { AUGUST } \\
26,1998\end{array}$} & WE3 & $\begin{array}{l}0.71(0.29) \\
0.12-1.20\end{array}$ & $\begin{array}{c}8.84(3.16) \\
1.99-13.2\end{array}$ & $\begin{array}{l}0.72(0.24) \\
\text { n.d. }-0.92\end{array}$ & $\begin{array}{r}4.54(1.99) \\
\text { nd }-9.38\end{array}$ & $\begin{array}{c}50.8(21.6) \\
17.4-89.8\end{array}$ & $\begin{array}{c}204(81.5) \\
50.8-286\end{array}$ \\
\hline & WEA & $\begin{array}{l}0.48(0.19) \\
\text { n.d. }-1.02\end{array}$ & $\begin{array}{r}9.32(3.82) \\
2.14-16.5\end{array}$ & $\begin{array}{r}0.83(0.35) \\
0.05-0.99\end{array}$ & $\begin{array}{l}5.97(2.08) \\
\text { n.d. }-11.2\end{array}$ & $\begin{array}{c}78.5(30.4) \\
18.5-123\end{array}$ & $\begin{array}{l}126(54.1) \\
23.4-152\end{array}$ \\
\hline
\end{tabular}

Values in parenthesis are the standard deviation, $\sigma_{\mathrm{a}-1}$; "means of duplicate analysis and 9 sampling; "minimum value; "maximum value; n.d. = not detected.

The high metal levels found in the river water samples might result from weathering and erosion of the waste material from industries or intentional dumping of industrial, domestic and municipal wastes into the river system.

Water quality criteria as set by EPA and WHO guidelines for potable water are an attempt to describe the river habitat in terms of the deleterous effects of pollutants on aquatic organisms and on human health. Acute standards or maximum permissible levels involve levels of metals that rapidly induce a negative response in an organism or produce undesirable effect in human being. A response to a lower concentration of metals over a longer period of time is the basis for the chronic standards or maximum admissible concentrations. The data showed that much of the river exceeded the chronic criteria levels for cadmium, copper and lead (Table 4). Since the analytical technique for the determination of chromium was only able to detect total chromium (i.e. $\mathrm{Cr}$-III and $\mathrm{Cr}-\mathrm{VI}$ ), a direct comparison with water quality criteria can only be done by assuming that the metal associated with the particulate fraction of the sample is $\mathrm{Cr}-\mathrm{III}$ and the dissolved fraction contains $\mathrm{Cr}$-VI. This assumption is based on thermodynamic and kinetic evaluations as specified in the literature [19]. Nevertheless, on this basis then, the entire river was above the chronic criteria for freshwater with respect to both $\mathrm{Cr}$-III and $\mathrm{Cr}$-VI. The concentration of nickel was below the chronic criteria for fresh water during the three surveys. The concentrations of all the metals analyzed in the groundwater samples were below the chronic criteria level, showing that there was low level of pollutional load of these metals in the groundwater, and thus indicates that there was no danger due to these metals to the consumers of the well waters.

The concentrations of cadmium, chromium, copper, lead and zinc are compared with maximum admissible concentrations recommended for drinking water quality $[20,21]$. The data showed 
that cadmium, copper, lead and zinc contents in all water samples were below the maximum admissible concentrations except chromium, which exceeded the maximum admissible concentration. The high chromium content can be due to leaching of wastes from metal plating industry lacated in the study area into the river.

Table 4. EPA water quality criteria for fresh water and WHO standards for drinking water.

\begin{tabular}{|c|c|c|c|c|}
\hline \multirow[t]{2}{*}{ Metal } & \multicolumn{2}{|c|}{ EPA water quality criteria ${ }^{1}, \mu \mathrm{g} \mathrm{dm}^{-3}$} & \multicolumn{2}{|c|}{ WHO standards, $\mathrm{mg} \mathrm{dm}^{-3}$} \\
\hline & Chronic & Acute & MAC & MPL \\
\hline $\mathrm{Cd}$ & 0.57 & 1.45 & 0.005 & 0.01 \\
\hline $\mathrm{C}_{\mathrm{T}}$ & 100 (Cr-III) & 842 & 0.05 & - \\
\hline $\mathrm{Ca}$ & $\begin{array}{c}11(\mathrm{Cr}-\mathrm{Vl}) \\
5.6\end{array}$ & 7.7 & 0.05 & 1.50 \\
\hline $\mathrm{Pb}$ & 1.05 & 26.97 & 0.05 & 0.10 \\
\hline $\mathrm{Ni}$ & 48.8 & 942 & - & - \\
\hline $\mathrm{Zn}$ & - & - & 5.0 & 15.0 \\
\hline
\end{tabular}

EPA: Environmental Protection Agency; ${ }^{1}$ Federal Register [22]; data is for a hardness of $41.3 \mathrm{mg} \mathrm{dm}^{-3} \mathrm{CaCO}_{3}$. WHO: World Health Organization; MAC: maximum admissible concentration; MPL: maximum permissible level.

To deduce the possible sources of the metal pollutants, one approach taken was to determine the correlation coefficients between element pairs. As seen in Table 5, significant correlation ( $p$ $<0.05 ; 16$ d.f.) does occur between $\mathrm{Cd}-\mathrm{Zn}, \mathrm{Zn}-\mathrm{Cu}$ and $\mathrm{Pb}-\mathrm{Cu}$ in the water samples from the high pollution source, thus suggesting a common source for the metals. There is low correlation ( $p<$ $0.05 ; 16$ and 4 d.f.) between other element pairs in both high and low pollution water sources, thus suggesting a non-common source of the metals. The probable sources of the metals in the river water and groundwater samples varied widely and may include leachates from wastewater generated domestically, industrially or municipally, and/or intentional dumping of agricultural waste or waste materials from industrial metal scraps, furniture, automobiles into the river water and from the natural weathering of rocks on land and volcanic activity, which eventually get eroded as run-off into the rivers and seas.

Table 5. Correlation coefficient between metal pairs in the water samples from two different sources.

\begin{tabular}{|l|cc|}
\hline \multirow{3}{*}{ Metal pairs } & \multicolumn{2}{|c|}{ Coefficient of correlation $\left(\mathrm{r}^{\mathrm{f}}\right)$} \\
\cline { 2 - 2 } & $\begin{array}{l}\text { High-poliution river } \\
\text { water }\end{array}$ & $\begin{array}{l}\text { Low-pollution } \\
\text { groundwater }\end{array}$ \\
\hline $\mathrm{Cd}-\mathrm{Zn}$ & 0.81 & 0.34 \\
$\mathrm{Cr}-\mathrm{Cu}$ & 0.47 & 0.40 \\
$\mathrm{Zn}-\mathrm{Cu}$ & 0.55 & -0.46 \\
$\mathrm{~Pb}-\mathrm{Cr}$ & 0.36 & -0.54 \\
$\mathrm{~Pb}-\mathrm{Zn}$ & 0.27 & 0.23 \\
$\mathrm{~Pb}-\mathrm{Cu}$ & 0.82 & -0.06 \\
$\mathrm{~Pb}-\mathrm{Ni}$ & 0.32 & 0.04 \\
$\mathrm{Cr}-\mathrm{Zn}$ & 0.37 & -0.54 \\
\hline
\end{tabular}

"Critical values of ' $r$ ' for 16 and 4 d.f. are 0.47 and 0.81 , respectively, at $95 \%$ confidence level. d.f. is degree of freedom. 


\section{REFERENCES}

1. Smith, R.A; Alexander, R.B; Wolman, M.G: Science 1987, 235, 1607.

2. Garric, J; Vindimian, E., Ferard, J.F. Sci. Total Environ. (Suppl.) 1993, 1085.

3. Pickering, K.T.; Owen, L.A. An Introduction to Global Environmental Issues, John Wiley: New York; 1997; Chap. 5, p 145.

4. Aston, S.R; Thornton, I.; Webb, J.S; Purves, J.B.; Milford, B.L. Water, Air, Soil Poll. 1974, 3,321 .

5. Abdullah, M.I.; Royle, L.G. Nature (London), 1972, 238, 329.

6. Pasternak, K. Acta Hydrobiol. 1973, 15, 145.

7. Pasternak, K. Acta Hydrobiol., 1974a, 16, 51.

8. Pasternak, K. Acta Hydrobiol. 1974b, 16, 273.

9. Ireland, M.P. Environ. Poll. 1973, 4, 27.

10. Thornton, I; Watling, H.; Darracott, A. Sci. Total Environ. 1975, 4, 325.

11. McLean, A.C.; Gribble, C.D. Geology for Civil Engineers, 2nd ed., John Wiley: New York; 1990.

12. OSCHC: Printout Journal by the Osun State Cultural Heritage Council (OSCHC), Osun State, Nigeria, 1991.

13. Fresenius, W: Quentin, K.E.; Schneider, W. Water Analysis - A Practical Guide to Physicochemical, Chemical and Microbiological Water Examination and Quality Assurance, Springer Verlag:New York; 1988.

14. American Public Health Association (APHA) Standard Methods for Examination of Water and Wastewater, 17 th ed., American Public Health Association (APHA), American Water Works Association (AWWA) and Water Pollution Control Federation (WPCF): New York; 1989.

15. Parker, C.R. Water Analysis by Atomic Absorption Spectroscopy, Varian Techtoon: Australia; 1972.

16. Forstner, U. Metal Concentrations in Fresh Water Sediments, Natural Background and Cultural Effects: Interactions Between Sediments and Fresh Water, Golterman, H.L. (Ed.), The Hague, Pudoc/Junk. B.V Publishers: Washington; 1977; pp 94-103.

17. Fortstner, U.; Wittmann, G.T.W. Metal Pollution in the Aquatic Environment, 3rd ed., Springer-Verlag: Berlin, Heidelberg, New York; 1981.

18. Kudesia, V.P. Water Pollution, 2nd ed., Pragati Prakashan: Meerut; 1980.

19. Cranston, R.E.; Murray, J.W. Limnol. Ocean. 1980, 25, 1104.

20. WHO Guidelines for Drinking Water Quality Recommendations, Vol. 1. World Health Organization: Geneva; 1984.

21. WHO Assessment of Fresh Water Quality-Global Environmental Monitoring System (GEMS) Report on the Related Environmental Monitoring, World Health Organization: Geneva; 1988.

22. Federal Register Water Quality Criteria; Availability of Documents, 1985, 50, 30781. 